\title{
Трансмедіальні наративи коміксової журналістики: світовий та український досвід
}

\section{Гудошник О. В.}

\author{
Дніпровський національний університет імені Олеся Гончара
}

У продовження дослідження документалізованого світового та українського коміксу, дана стаття презентує коміксову журналістику у контексті різних теоретичних підходів, жанрових та тематичних визначень і характеристик. Опорний термін роботи - коміксова журналістика - розглядається як «парасольковий», що дозволяє об'єднати інтерактивний коміксрепортаж, карикатуру, пітч, графічний роман у єдиний простір графічного сторителінгу. Трансмедіальність коміксу, породжена візуалоцентричністю сучасного світу та схильністю до міксування різних форм та стилів, забезпечує журналістським матеріалам емпатичність, емоційність, інтертекстовість. При цьому традиційні журналістські стандарти не спростовуються, їх сенс і значення умотивовуються новими інформаційними викликами та технологічними можливостями сучасного графічного мистецтва. Так, визначальним і найдискутованішим питанням виявилося дотримання вимог об'єктивності та достовірності комікс-журналістами. Спираючись на стратегії візуальної достовірності (за теорією W.Weber та H.-M. Rall), у роботі ми схарактеризували матеріали української тематики на світових комікс-платформах і сайтах газет та національний контент української коміксової журналістики. Останній представлений окремими авторськими проєктами газет, новинних сайтів, блогів, циклами графічних історій соціальної проблематики, графічними романами та комікс-буками. Попри зацікавленість українського інформаційного простору в альтернативних формах представлення актуального соціального та політичного матеріалу, звернення до коміксової журналістики не узвичаєне практиками національних ЗМІ, масовими авторськими та громадськими ініціативами.

Ключові слова: документалізований комікс; коміксова журналістика; трансмедіальність; графічний сторителінг; стратегії достовірності.

\section{1. Вступ}

Постановка проблеми. До історії питання. Сприйняття коміксу зазвичай було скептичним через розуміння коміксової традиції як розважальної, тим більше це стосувалося журналістики, де суб'єктивність бачилася порушенням стрижневих засад професії [1, p. 378]. Comics journalism як напрямок у розвитку нон-фікшн коміксу (дана стаття $€$ продовженням дослідження documentary comics [2]) осмислюється сучасною критикою у мультидисциплінарному контексті трансмедіальної наратології і певною мірою виправдовує майже класичне визначення, запропоноване С. Макклаудом: «Вид мистецтва (медіум), знаний як комікс, - це ємність, що може вмістити безліч ідей та образів [3, с. 8]... А кожний медіум - місток між свідомостями нас, що глибоко ізольовані від інших» [3, с. 194-195].

Давній союз журналістики та коміксів у різні часи був актуалізований:

Hudoshnyk O., Candidate of Philological Sciences (Ph. D.), Associate Professor, Associate Professor of the Department of Mass and International Communication, e-mail address: ovgudoshnik@gmail.com, tel.: +380563731233 , ORCID: http://orcid.org/0000-0002-5941-4502, Oles Honchar Dnipro National University, 13, Naykova Str., Dnipro, 49050, Ukraine
- видавничими практиками, адже історія коміксів розпочиналася в газетах і журналах, лише у США сьогодні видається 119 найменувань комікс-журналів та антологій;

- масовою культурою через створення образів журналіста-одинака/репортера/героя: Тентен (Жорж Ремі (Ерже ${ }^{1}$ ), Спайдер Ієрусалім (У. Єлліс, Д. Робертсон. Трансметрополітен), Джей Джона Джеймсон («Людинапавук»), Десниця (Дж. Хікман. Нічні новини), Лоїс Лейн («Супермен»), Бен Уріх («Шибайголова»);

- кардинальними змінами у розумінні можливостей мистецтва послідовного зображення відтворювати нонфікшн контент.

У процесі розширення і осмислення цих нових можливостей фактор авторського самовизначення та вплив культурологічних дискусій відігравали вирішальну роль.

Так, 1990-ті для мистецтва коміксу виявилися знаковими. Принципова дискусія навколо меж високого і низького мистецтва була спровокована музейною виставкою «Високе і низьке: сучасне мистецтво [й] популярна культура (Музей сучасного мистецтва Нью-

Гудошник О. В., кандидат фрілологічних наук, дочент, доцент кафедри масової та міжнародної комунікації, електронна адреса: ovgudoshnik@gmail.com, тел.: +380563731233, ORCID: http://orcid.org/0000-0002-5941-4502, Дніпровський національний університет імені Олеся Гончара, вул.Наукова, 13, Дніпро, 49050, Україна

\footnotetext{
${ }^{1}$ Видання «Тентен. Репортер XX століття у країні Сов'єтів» в українському перекладі вийшло у видавництві PNZL у 2019 р.
} 
Йорка, 1990), де представлені американські комікси власне і визначалися як «низьке». Обурення коміксспільноти Арт Шпігельман відтворив у коміксі «Високе мистецтво: вид знизу», а виставка 2005 р. "Майстри американського коміксу» (Музей Хаммер, Музей сучасного мистецтва Лос-Анджелеса) остаточно завершила безперспективне протистояння. Завдяки видавництву IST Publishing (редактор Б. Філоненко) українські читачі можуть ознайомитися з обріями цієї запеклої дискусії: прочитати інтерв'ю, комікс-маніфест, критичні есеї [4].

На хвилі складного процесу самоусвідомлення стандартів і канонів нового/старого мистецтва Арт Шпігельман у 1992 р. отримує найвідомішу журналістську премію - Пулітцерівську - у номінації «Спеціальна нагорода» з чи не найкоротшим поясненням за всю історію: «For Maus», а його романи циклу «Маус» (1986, 1991, 2011) стають взірцевими у напрямку як documentary comics, так і graphic journalism.

Заради справедливості зазначимо, що, у продовження традиції підпільних коміксів унаочнювати свою «інакшість» через назву (commix, остання літера - сигнал про віковий поріг для аудиторії), А. Шпігельман намагався відокремити мистецтво серйозного коміксу від розважальних та бульварних його форм. у 1988 р. для журналу Print пише статтю «Commix: An Idiosyncratic Historical and Aesthetic Overview», в якій написання подвійного mm пояснює бажанням відокремитися від простору комічного, смішного та відтворити у слові міксування тексту, малюнків та сторителінгу.

У не менш дискусійному просторі вибудовував свою стратегію презентації новітнього напрямку і фундатор жанру Джо Сакко, автор графічного роману «Палестина» $(1993,1996)$, засадничого твору у розумінні коміксової журналістики. У 2012 р. він випускає збірку своїх графічних репортажів [5], де в передмові «A Manifesto Anyone?» легітимізує напрямок комікс-журналістики і чітко пояснює обмеженість об'єктивності як стрижневого фактору журналістики у цілому. Звернення до найважливіших істин, а не буквальної правди зумовлює, 3 його точки зору, критерій зображальної правдивості. Більше того, Д. Сакко кидає виклик «священним» засадам американської журналістики - об'єктивності та балансу. Ілюзорність (чи принаймні спірність) апологетики неупередженості та нейтральності коміксист пояснює правом журналіста на вибір кута зору і підтримку тих, хто страждає [5, р. XIV]. В інтерв'ю того ж року Д. Сакко підкреслює відповідальність графічного журналіста за цей суб'єктивний пошук істини: якщо ви бачите речі, які не відповідають вашому світогляду, ви все одно повинні повідомити про них [6].

Ден Арчер, автор сайту archcomix.com, де представлені комікси соціальної тематики та політичні карикатури, на 17 панелях виклав засадничі принципи нового виду графічного мистецтва: журналіст-коміксист досліджує та розслідує (research + investigate) історії традиційно, але подає їх як комікс, а не як звичайний текст, фото або відео. У короткій лекції на сайті [7] до обов'язкових прийомів графічної журналістики блогер відносить: інтерв'ю, усні свідчення, візуальні пояснення, відтворення об'єктивності, візуалізований виклад даних. Д. Арчер виокремлює три групи наративів: тексти авторів, що власноруч виконують роботу репортера, письменника та художника (Д. Сакко, Тед Ролл, сам Д. Арчер); напрямок, що об'єднує журналістику та коміксмейкерство (видання EXTRACTION!: Comix Reportage) і нон-фікшн комікс, що представляє історичні, літературні та наукові теми. Високочолі дискутанти також представлені у коміксі Арчера: професорського вигляду чоловік зарозуміло говорить про неможливість відтворення новин у комікс-форматі через апріорну суб'єктивність малюнка.

Редакторка сайту коміксової журналістики Symbolia Ерін Полгрін інфографічну журналістику, що актуалізує нюанси та медитативну глибину при створенні репортажів [8], визначає як барвисту суміш впливів, що включають комікси, інфографіку, фільм та автобіографію. До різновидів відносить: травелоги, портрети, досвід власних пригод, об'єднання мультимедіа. Різницю між традиційною та коміксовою журналістикою вбачає у можливості експериментувати 3 динамічними розповідями, власноруч створювати особистісне відчуття; кожна історія повинна бути своєчасною, але не залежною від часу [9]. Як бачимо, простір потрактувань новітнього явища comics / graphic journalism залежав як від авторського розуміння журналістських засад взагалі, так і від особистісного художнього досвіду. Неоднозначними бачаться і численні розвідки сучасних комікс-критиків.

Аналіз останніх досліджень. У 2010-х рр. розпочинається активне звернення до коміксових форм у інформаційному, культурному просторі, новітні проєкти з'являються у царині історії, літератури, напрямку емпатичних медіа тощо. Ф. Алдама, презентуючи книгу «Comics Studies Here and Now» (2018), пише: сьогодні ми сміливо можемо говорити про комікс-дослідження як «повноцінні дисципліни, які розкопують, вивчають, обговорюють та аналізують усі аспекти нашої чудової планетарної Республіки коміксів» [10].

Серед загальних ідей нового підходу до жанру виокремимо наступні.

1. Графічна та коміксова журналістика поступово розводяться у термінологічному та сенсовому значенні. Перша, попри розуміння графічного репортера як оповідача і художника, все ж зосереджена більше на ідеографічних елементах, мультимедійності, інтерактиві. Так, у практичному посібнику для репортерів «A practical guide to graphics reporting» (2017) [11] схарактеризовані різні графічні елементи та особливості їхнього використання в тексті.

Л. Шліхтінг [12] диференціює інтерактивну графічну журналістику, з наявністю у ній інструментів графічних медіа (фотографії, карти, інфографіка, відео тощо), та власне comics journalism як напрямки дотичні (коміксова журналістика - різновид графічної), але не тотожні: попри великий потенціал альтернативних форм журналістики та схожість змісту, авторка розводить за способом реалізації цього змісту публіцистичну комікс-книжку та журналістику веб-коміксів. Так, комікс Д. Арчера 
«The Nisoor Square Shooting» (2010) авторка відносить до інтерактивного сторителінгу, де технологічні засоби використовуються для створення інноваційних елементів оповідання сюжету. Графічна журналістика, на думку авторки, дозволяє привернути увагу читачів поліфонією голосів, можливістю скласти свою думку оптимальним відтворенням усіх подробиць події у стислій цифровій візуально привабливій та структурованій формі.

Засоби представлення текстових та образотворчих наративів у графічній журналістиці досліджував Т. Щак [13]. Графічна журналістика як незагайний засіб (immediate medium (за Д. Сакко) опинитися у вирі подій минулого породжує емоційну безпосередність, атмосферний зміст, підкреслений деталізацією простору та часу та особливе налаштування аудиторії («клейкість») на багатошарову розповідь із «невблаганною пріоритетністю візуального зображення» [13, р. 110-116].

2. Коміксова журналістика набуває статусу окремого об'єкта наукових розвідок у напрямку аналізу соціальних коміксів. Пропонується розуміння коміксу у цьому термінологічному гібриді не як повноцінного жанру, а «як засобу представлення серйозних тем, фактів і новин» [14, p. 349]. Комікс у такому потрактуванні виступає посередником, медіумом, що дозволяє у новій формі графічного сторителінгу звернутися до важливих соціальних тем чи переосмислити травматичне минуле. Більше того, і до сьогодні життєпис (автографіка) визнається ключовим виправдовувальним доказом повільного переходу коміксів «від м'якотілого сміття до важливої оповідної та суспільно-політичної форми» [15].

у цьому напрямку значна кількість публікацій зосереджена на аналізі тематики та представленості типологій за проблематикою. Нон-фікшн комікс об'єднує журналістику, мемуари, історію та освіту. Ці напрямки розглядаються у підсумковій науковій збірці «Creating Comics as Journalism, Memoir and Nonfiction» (2016) [16] різні форми документалізму злиті у загальний тип нонфікшн, а історія поєднання коміксу та журналістики ілюструється довільно обраними прикладами візуального супроводу новин. Таке широке тлумачення коміксової журналістики підкріплюється структурною схемою (iї практична реалізація і запропонована у книзі): інкапсуляція (зосередження уваги на головному), композиція (творчий відбір елементів) та макет (послідовні просторові відношення) [16, р. 79-80]. Дослідження форм соціальної актуалізації минулих подій, комеморації як вирішального сенсу, дискусійність суб'єктивованої оцінки доповнюються у збірці практичними рекомендаціями (техніки нарації, образотворчі методи, поради щодо виробництва, юридичного супроводу, етичних конфліктів).

Соціальна спрямованість коміксів, візуальне представлення реальних історичних фактів та подій актуалізує різноаспектні наукові підходи до розуміння принципів трансмедіальності коміксу як «стратегії представництва» (за Н. Міквіц [17]).

Обговорення і дослідження дискурсу національної ідентичності представлене у роботі Л. Висоцькі, де наведені результати відповідей на анкету (у вигляді коміксу) щодо обізнаності в історії британських та світових коміксів і зосереджено увагу на багатошаровому підході до визначення «соціально побудованих розумінь національної ідентичності В контексті посилених дискурсів “британства"» [18, р. 520].

Можливості представлення актуальної соціальної тематики у вигляді графічних романів та журналістських комікс-репортажів, особливо у напрямку поширення знань про права людини та захист постраждалих, досліджували у педагогічному аспекті викладання через т. зв. «емоційну історію», де співпереживання та емпатія стають основою особистісного усвідомлення історичних подій [19, р. 17]. Історія та хронологія співпраці коміксистів та руху за права людини за останні 30 років представлена у роботі Ш. Салмі [20]. Авторка не виокремлює різновиди коміксів на соціальну тематику, одним просвітницьким завданням об'єднує як інформаційні комікси правозахисних організацій для розповсюдження знань про міграцію, расизм та ксенофобію в Європі, боротьбу з насиллям над жінками в Індії, права дітей в Камбоджі, проблеми дискримінації лГБТ в Австралії, так і репортажі та книги Д. Сакко, М. Сатрапі, С. Глідден, Е. Мура. Для авторки важливою $\epsilon$ представленість «архетипної долі людини, яка підштовхує до співчуття» [19, р. 181-182], наприклад, у коміксі про імміграційні центри біженців в Австралії (At Work Inside Our Detention Centres: A Guard's Story. Global Mail). Кайротична природа репортерських свідчень виступає засобом переконання для певного часу [19, р. 188]. Більш чітко увиразнити особливості репортажів з проблем прав людини та коміксову журналістику намагаються Дж. Бейк та М. Зерер [20]. На прикладі репортажів правозахисної громадської організації Human Rights Watch та робіт Джо Сакко актуалізуються два підходи до відтворення дійсності: наочне візуальне представлення зібраних у «польових дослідженнях» свідчень та доказів і уособлення істини у фігурі свідка через навіювання чуттєвої безпосередності [20, р. 94]. Різне розуміння фактажної та емоційно-емпатичної істинності диктує різні художні засоби.

Коливання між історією та автобіографією як наскрізну ідею творчості Сакко аналізує Дж. Кавалоскі [21]. У розумінні історичного часу дослідник виокремлює головну відмінність ЗМІ та коміксової журналістики: поточні новини - це комерційний товар, його вартість залежить від своєчасності та сенсаційності, коміксдискурс функціонує без тиску часу: «загальний континуум, але з різним ставленням до тимчасовості». У свою чергу, цей часовий тиск дозволяє через розуміння минулого трансформувати наше розуміння сучасного [21, p. 128].

3. Коміксова журналістика як парасольковий термін.

Розуміння коміксу у широкому контексті синтетичних мистецтв - ідея не нова. У колективній монографії 2010 р. "Comics as a Nexus of Cultures: Essays on the Interplay of Media, Disciplines and International Perspectives» представлені здобутки та перспективи коміксів та графічних романів в аспекті взаємодій популярного та високого мистецтв (адаптації до фільмів, манга, комікс- 
журналізм), а також міждисциплінарний підхід до трактувань цих явищ у культурному просторі США, Канади, Великобританії, Португалії, Німеччини, Туреччини, Індії та Японії [22].

Роботи останніх років пропонують ускладнене сприйняття коміксової журналістики у наступних аспектах: формування новітніх наративних форм; розвиток візуальної культури; становлення жанрів повільної журналістики; право на суб'єктивну думку / неможливість у сучасному світі об'єктивної істини.

Так, А. Сеєда та Д. Хеба визначають графічну/коміксову журналістику як парасольковий термін для «журналістики, яка використовує комікси як засоби для висвітлення нонфікшн подій» [23, р. 529]. Поширення явища пов'язане 3 одночасними процесами змін у самій журналістиці перехід до візуалоцентричності як методу певного спрощення і засобу створення абсолютно нової емерсивної та інтерактивної журналістської платформи [23, р. 530]. «У сьогоднішньому цифровому світі, де користувачі керують змістом, графічна розповідь $€$ ще однією додатковою перевагою залучення читачів на рівні, якого традиційний журналістський репортаж навряд чи може досягти» [23, p. 542]. Це вимагає додаткового часу, створювати такий текст може людина, що розбирається у подіях, готова нести відповідальність за представлений (зазвичай, суб'єктивний і незбалансований) погляд на трагічні події. При цьому візуальний наратив забезпечує полімодальність, чим розширює читацькі інтертекстуальні уявлення та реакції. У свою чергу, це вимагає формування власної теорії графічного сторителінгу (на сучасну комікс-критику, на думку авторів, тисне текстова теорія наративу) та візуальної риторики, для визначення якої автори пропонують наступні характеристики:

1. Використання зображень в якості аргументу.

2. Впорядкування елементів на сторінці.

3. Використання типографських технологій (шрифти тощо).

4. Аналіз існуючих образів та візуальних зображень.

Власне автори визнали неподільність зображення та слова у графічній журналістиці, обгрунтували термін graphic narrative, визначили його як засадничий для різних видів послідовного мистецтва (visual narrative, pictorial narrative, sequential narrative, sequential pictorial narrative, sequential storytelling, graphic literature, or narrative illustration [23, p. 536]).

Використання коміксів/графіки змушує читача більше втягуватися в історію, а не триматися осторонь, як це відбувається з традиційним репортажем. Напруга між написаним словом та зображенням може бути використана для висвітлення невизначеностей, неоднозначностей та іроній, які іншіми ЗМІ можуть ненавмисно чи навмисно ігноруватися.

До визначення поняття. Парасольковість терміну та можливість заміни у сучасній комікс-критиці не сприймається як теоретична невизначеність. Дослідник К. Кочаk пропонує не боятися вживати різноманітні терміни: comics journalism, reportage drawing, graphic journalism, observational cartooning, documentary illustration, and subjective visual reportage [24, р. 192], адже усі вони у тій чи іншій мірі є «проявами гібридного жанру, який завжди зберігатиме елемент ілюстративного візуального походження». Коміксова журналістика, за визначенням автора, "відтворене за посередництвом коміксу правдиве повідомлення для читачів або про досі невідоме минуле, або про нові особливості актуального соціального чи політичного світу, що змінюється» [24, р. 195]. Більш дотичним до журналістської практики бачиться визначення У. Вебера та Х.-М.Ролла коміксової журналістики як послідовного мистецтва, що використовує комбінацію візуальних і словесних знаків задля показу заснованих на фактах новин, будь то друковані або онлайн чи цифрові. Комунікативна функція жанру полягає в тому, щоб інформувати, розповідаючи, описуючи і пояснюючи, і при цьому сприяти формуванню громадської думки відповідно до журналістських стандартів [1, p. 379]. Принципову різницю між графічними романами та коміксовою журналістикою автори вбачають у можливостях коміксмейкерів творити у трьох площинах: діяти як збирач інформації (тобто повідомляти, фізично діставатися в «поле», обирати теми інтерв'ю, шукати документи, текстові та візуальні тощо), а потім виступати як письменник і художник [13, р. 110; 1 , p. 376]. Факторами достовірності й надійності авторських візуальних стратегій дослідники визначають: присутність автора, фізичну подібність, стилістичні прийоми, документальні свідчення та мета-історію (частково це актуально і для journalistic data stories [25]). Стратегіï достовірності - будь-то візуальні чи словесні - необхідні, якщо комікс-журналісти хочуть здаватися надійними. Візуальні (та словесні) підказки дозволяють читачам відрізняти вигадані комікси від публіцистичних (не вигаданих) коміксів [1, р. 391].

Мета дослідження - презентувати коміксову журналістику у теоретичному, історико-журналістському вимірі, схарактеризувати українські трансмедіальні комікс-наративи у контексті світового розвитку документалізованого коміксу.

Об'єкт вивчення - коміксова журналістика у загальному контексті комікс-критики та реальному просторі журналістських практик.

Методи дослідження. Загальнонауковий описовий метод дозволяє представити засадничі принципи функціонування коміксових видів журналістики, сформувати загальне уявлення про досліджуваний об'єкт; метод порівняння та аналізу застосовано до графічних практик українських та зарубіжних авторів. Разом з тим занадто широке потрактування коміксової журналістики як парасолькового терміну, а також активні спроби самовизначення жанру самими комікс-журналістами змушують, принаймні абрисно, обмежити вибір корпусу текстів відповідного жанру. Оскільки автор є ключовим чинником графічного сторителінгу, стратегії візуальної достовірності, запропоновані У. Вебером та Х.-М.Роллом, ми розглядаємо як метод ідентифікації та визначення текстів графічної/коміксової журналістики. До них відносять:

1. Присутність автора-журналіста, який виступає як очевидець або інтерв' юер (персонажне втілення автора у коміксі, оповідь від першої особи (Я, ми). 
2. Фізична схожість: подібність реальним людям журналіста, героїв, персонажів, експертів; надання фотодоказів.

3. Візуальні стилістичні прийоми (колір, тони, світло, відтінок, виготовлення позначок, мовленнєві кулі, рукописні або комп'ютерні позначки, розмір та форма панелей та макет сторінки) постійно нагадують читачеві про онтологічну суб'єктивність публіцистичного коміксу.

4. Документальне підтвердження шляхом надання оригіналів та скринів документів (статистичні дані, діаграми, карти, інтерв'ю з вченими чи експертами, контекстні матеріали, інтерактивні графіки чи відео).

5. Мета-історія, яка розкриває виробничий процес, дослідження, методи, джерела, щоб аудиторія могла зрозуміти, які дії виконувалися [1, р. 390].

\section{2. Результати дослідження}

Попри вже усталену думку [1; 13; 23; 24], що історія коміксової журналістики починається 3 традицій, а скоріше, їі порушень андеграундним коміксом 19601970-х рр. (Роберт Крамб, Харві Пекар, Харві Курцман), ключовим моментом для створення нового коміксу став, як вважають дослідники, «Контракт 3 богом» Віла Айснера (1978р.). 4 новели 3 повсякденного життя арендного дому № 55 на Дропсі-Авеню у Нью-Йорку вперше унаочнили тезу, пізніше сформульовану Макклаудом: «комікс - одна з дуже небагатьох форм масової комунікації, де досі можна почути індивідуальні голоси» [3, с. 197]. Повсякденність подана через життєві історії персонажів 3 міксуванням художнього та автобіографічного (фактажного) і може розглядатися як нова життєписна форма, новий для свого часу наратив, породжений відкриттями Нового журналізму. Так, серед рис, що поєднують Новий журналізм та коміксову журналістику, виокремлюють наступні: звернення до соціальних, соціально-політичних, культурних та субкультурних явищ; об'єднання фактологічно точної інформації з літературними прийомами написання прози чи художньої літератури; використання діалогів, часто у розмовному тоні; зосередження на детальному спостереженні за буденним життям та занурення в події; створення емоційної безпосередності; зосередженість на суб'єктивному; давня нон-фікшн традиція [1, р. 382-383]. К. Кочак звертає увагу на подібність Нової журналістики 1960-1970-х, як голосу контркультури, та «інакшість» сучасної коміксової журналістики для представників традиційної 'dominant' journalism [24, p. 187].

Стрімкий розвиток коміксової журналістики як новітньої трансмедійної форми, активне її використання у практиці правозахисних організацій, у просуванні соціальних проєктів пов'язують 3 подіями 11 вересня 2001 р., після яких кількість соціальних коміксів збільшилася утричі. «Можна стверджувати, що коміксжурналісти мали місію - місію інформувати людей по всьому світу про те, що дійсно відбувалося в так званих країнах "осі зла" та на Близькому Сході» [24, р. 189]. Політична та соціальна акцентуація залишаються визначальними для жанру й до сьогодні. Попри різновекторні підходи у розумінні напрямків та специфіки коміксової журналістики сучасною критикою, простір реальних наративів багатший, а синтетичність проявів багаточисельна. Залишається актуальним і фактор самовизначення авторами належності своїх творів до досліджуваного напрямку. Так, поширеною практикою стало залучення до комікс-контенту карикатур. Документація реальних подій засобами послідовного візуального сторителінгу дозволяє, на перший погляд, провести кордон між політичною карикатурою та ії видами й коміксовою журналістикою. Разом 3 тим карикатура виступає своєрідним документом епохи чи реальної події, і в цьому розумінні дослідники не виводять її за межі синтетичних жанрів. Так, у книзі «From Comic Strips to Graphic Novels: Contributions to the Theory and History of Graphic Narrative» графічні наративи об'єднуються в межах трансмедіальної та міждисциплінарної наратології загальним розумінням посередництва, медіації, як матеріальної сторони знаку/семіотичної системи при виробництві наративного сенсу. «Наративність - це когнітивний макрокадр, який потрібно активувати в різних середовищах» [26, р. 123].

Попри бажання розвести карикатуру і графічні романи за принципами документалізму, наявності/відсутності комічного, присутності автора та часовою дистанційованістю у реальному просторі світового comics journalism, різні жанри легко уживаються поряд, а іноді на одних платформах.

Поява великих платформ для розміщення різножанрових творів візуальної журналістики (карикатури, пітчі, стрипи, комікси) породжена карколомними змінами у сфері видання друкованої продукції. Об'єднання художників, карикатуристів, коміксмейкерів - загальна давня практика видавничого процесу, актуальна і в сучасному просторі візуальних мистецтв.

Найвідоміші cartoon-платформи за логікою представлення різних форм графічного мистецтва містять як традиційні політичні карикатури, так і коміксрепортажі, стрипи та пітчі. Так, на глобальній платформі cartoonmovement.com, що позиціонує себе як видавнича площадка № 1 для високоякісних карикатур та коміксжурналістики, представлені роботи більше 450 художників з майже 100 країн світу, в колекції онлайнплатформи - 50 тис. коміксів та карикатур. У 2017 р. ресурс отримав фінансування від Google Digital Media Initiative задля розширення технічних можливостей підтримки якісного контенту. У розділі Comics Journalism опубліковані 99 різнотематичних репортажів про протести у Гонконзі, мігрантську кризу, трагедію в Уганді тощо. Власне тут розміщені найвідоміші комікси Дена Арчера («The Nisoor Square Shootings»), Сари Гліден («The Waiting Room»), Стефані МакМілан («American Fall»), Теда Ролла («Quebec's Not-So-Quiet Revolution»). Примітний i слоган ресурсу - There is more than one truth - втілюється у різних за політичними поглядами публікаціях. Помітно це при розгляді українського тематичного контенту. Українські політичні події та українські автори широко представлені на ресурсі - більше 1,5 тис. пітчей (pitch), 
близько 10 постійних авторів 3 високим рівнем коментування: В. Казаневський (40 карикатур, 404 pitches, 1105 коментарів), О. Кустовський (11 карикатур, 70 pitches, 369 коментарів), С. Федко (8 карикатур, 1072 pitches, 930 коментарів), Є. Олійник, І. Лук'яненко, О. Дубовський. Певною мірою це відбиває загальну тенденцію виходу українських карикатуристів на міжнародний рівень. Так, всесвітньовідомою у 2019 р. стала карикатура Сергія Майдукова на прем'єр-міністра Британії Бориса Джонсона і президента США Дональда Трампа, надрукована на обкладинках лондонського та нью-йоркського випуску газети The Guardian Weekly від 4 жовтня 2019 р. Олексій Кустовський був членом журі престижного конкурсу 1st Welt Heimat «War and Humanity» International Cartoon Contest (Німеччина, 2018), а дніпровський художник Олександр Дубовський став його фіналістом.

Як платформу для графічної журналістики позиціонує себе ресурс drawingthetimes.com, який, власне, і розміщує різні за обсягами та тематикою журналістські роботи художників більше ніж з 80 країн світу. За задумом, автори у жанрі non-fiction visual stories намагаються «інформувати, розважати та залучати читачів до глобальних проблем та локальних історій». Так, продовжуючи традицію створення коротких посібників, на кшталт «What is Comics Journalism?» Д. Арчера (2011), у 2014 р. Ева Гілхорст, редакторка веб-сайту, розміщує на ресурсі свій варіант "Graphic Journalism. An Introduction to Graphic Journalism», де звертає увагу на найбільш складні та дискусійні аспекти коміксової журналістики: питання об'єктивності, сценарного комбінування думки та факту, представленості автора, етичності зображення. Контент publishing website організовано нелінійно: матеріали представлені як за проблематикою (культура, економіка, суспільство, освіта, навколишнє середовище, здоров'я, секс та гендер, фемінізм, права людини, кліматичні проблеми, імміграція тощо) так і за формами подачі матеріалу (анімація, карикатура, комікс, інфографіка, інтерактив, репортаж). Серед авторів - опозиційний графічний репортер Вікторія Ломаско, яка видала у 2017 р. книгу «Other Russia» 3 портретами та замальовками повсякденного провінційного життя звичайних росіян. На веб-сайті представлені подорожні репортажі їі поїздок до Тбілісі, Дагестану, Киргизстану та Єревану.

Неодноразові номінанти премії Віла Ейснера, редакційна група інтернет-видання The Nib з 2013 р. активно шукає нові форми залучення читачів до контенту та підтримки своєї незалежності. Попри припинення фінансування у червні 2019 р., ресурс спирається на допомогу підписників і проєкти краудфандінгу (наприклад, збір коштів на книгу «Be Gay, Do Comics» комікс-антологію історій, мемуарів та сатири), активно розширює тематичну палітру контенту (квір-тематика).

Разом з тим проблеми у роботі цих платформ пов'язані з одним із негативних трендів останніх років зменшенням присутності карикатури в сучасних газетах. За даними Herb Block Foundation Report, 32000 редакційних карикатуристів в американських газетах залишилося 40. 31 липня 2019 р. міжнародна версія The
New York Times International Edition припинила друкувати політичні карикатури, а після скандалу з карикатурою на Д. Трампа та Б. Нетаньяху видання розірвало контракт із синдикатом CartoonArts International, потужним постачальником відповідної продукції у світові газети (550 художників з 75 країн). Реакція на рішення газети The New York Times не друкувати політичні карикатури, тематичні блоки представлена на cartoonmovement.com.

Другий напрямок реалізації коміксової журналістики у вигляді циклу репортажів, стрип-історій чи розгорнутих коміксів представлено на сторінках періодичних видань. Комікс-репортажі - розвинута система відтворення подій у максимально короткому хронотопі. Газетна періодика сьогодні в активному пошуку візуалізованих форм подієвої нарації активно звертається до коміксистів, замовляючи як стрипи, так і серійні підборки тематичних графічних репортажів. Серед них вже практично взірцеві та класичні.

У розділі Opinion газети The International New York Times y 2016 р. було опубліковано графічний цикл з п'яти cepiй «Inside Death Row» журналіста Патріка Чаппате та його дружини Енн-Фредерік Відманн, у яких відтворено серію інтерв'ю із засудженими до смертної кари (показово, що представлені ці стрипи були спочатку на виставці «Мистецтво та документ»).

Для пояснення висновків та рекомендацій 586сторінкового звіту Національної комісії з питань терактів щодо подій 9/11 С. Джекобсон та Е. Колон створюють графічний роман-репортаж «The 9/11 Report: A Graphic Adaptation», який представлено газетою USA Today [27]. Хроніка подій 11 вересня 2001 р., відстеження історій чотирьох літаків виступають, як вказано у рецензії The New York Times до книги, «не лише приголомшливим документом новітньої історії, але й доказом сили коміксів» (The New York Times. 2019. 16 August) Сам С. Джекобсон в інтерв'ю 2016 р. назвав жанр своєї книги graphic journalism, підкреслюючи відмінність від традиційних графічних романів та коміксів, а завданням визначив позиціонуваня читача (цит. за: [28]). В інтерв'ю USA Today автори чітко підкреслюють: «Це не комікс і не драматизація, це історія розслідування. Це графічна журналістика» (USA Today. 2006. 22 July). Часова шкала як композиційний стрижень, дотримання нейтральності у викладенні матеріалу, несенсаційність зображень, підкреслена документальність звернень до звіту - все це, на думку авторів, наближає текст видання до власне журналістики.

Глибоку традицію поширення історичних, подорожніх, подієвих комікс-репортажів, сталий інтерес до біографій у вигляді графічних новел і романів демонструє німецькомовний простір. Так, у 2011 р. німецька Frankfurter Allgemeine Zeitung надрукувала 111 стрипів «Der Boxer» про життя у концтаборі єврейського боксера Герцька (Гаррі) Гафта, яку розповів його син; повна версія книги відомого художника Reinhard Kleist («Der Boxer: Die Überlebensgeschichte des Hertzko Haft») війшла у 2012 р. Перспективною бачиться академічна співпраця німецьких установ (Гете-Інститут) 3 українськими коміксмейкерами, проведення майстер- 
класів та семінарів (2016 р., Львівський Форум видавців). у 2016 р. результатом проведення комікс-воркшопу при Goethe-Institut стало видання першої української коміксгазети «Сковорода».

Сайт англійської газети The Guardian містить розділ «Guardian Opinion cartoon», в якому щоденно представлені карикатури та стрипи на злобу дня 3 численними доволі в'їдливими коментарями під кожним. 9 серпня 2019 р. на сайті газети у серії «The illustrated city» було опубліковано комікс-репортаж про події листопада 2013 р. - лютого 2014 р. в Україні «They have bullets. We have the city" австралійського художника Алекса Павлоцького. Історія поділена на чотири частини: Euromaidan: The City as a Weapon (Євромайдан: місто як зброя); Euromaidan: The Camp in the City (Євромайдан: табір у місті); Euromaidan: The War Zone (Євромайдан: територія війни); Euromaidan: The Tent Village (Євромайдан: наметове містечко). У коміксі активно використовуються журналістські прийоми, намагання об'єктивувати передані події через голоси героїв (тут і реальні Янукович та Кличко, Pravyi Sector (right sector) та Свобода), документальні врізки з фактажем, геолокаційні визначення міста, вулиць, проспектів та площ, активне використання образів та назв, що стали мемами: Новорічна ялинка, barricade, Babushka 3 каструлею на голові.

Комікс-серіал про абсурдні історії російського судочинства, а також коментарі спеціалістів до кожної справи з 2018 р. публікує «Новая газета» у судовосатиричній рубриці «Кафка-кодекс».

Українська коміксова журналістика представлена редукованими або синтетичними формами стрипів, мемів, карикатур і тематичних малюнків. Власний жанр медіакомікс - придумала художниця та дизайнерка О. Васьків-Кукіл. Авторка блогу Mediacomics в інтерв'ю схарактеризувала жанр графічного репортажу як інструмент сторителінгу: «Головне завдання коміксу - це visual storytelling, вміння розповісти історію в картинках, коли слова неважливі або недієві... Художник-журналіст це дуже рідкісна професія сьогодні. Але саме ця людина може розповісти дуже серйозну і важливу історію, історію людини, яка воліє не показувати власного обличчя, але й не хоче губити свою особистість. Ну а між графічним репортажем і медіакоміксом я все-таки ставлю певну межу, тому що Медіакомікс - це все-таки іронічнорозважальний блог, а не репортаж чи політична карикатура» (hromadske.lviv.ua. 2016. 31 травня).

Розділи коміксів представлені і на регіональних новинних сайтах. Харківський новинний портал Город X (gx.net.ua) уміщує більше 400 коміксів про звичайну харківську родину Маламет, кожний представник якої унаочнює типові соціальні, професійні, гендерні риси середнього пересічного українця: тато - інженер, безробітний, поціновувач рибалки та садівництва; мама вчителька, мрійниця і реалістка одночасно; дочкастудентка мріє про модельну кар'єру; син-третьокласник, геймер і програмер. Герої представляють різні точки зору на актуальні теми, розповідають про відомих містян, історичні хроніки, дають поради, як убезпечити себе від хвороб, зібрати домашню аптечку, вдало відпочити, відсвяткувати, захистити дітей від небезпек тощо. Кожний сюжет завершується фактологічною врізкою, зазвичай, 3 нормами законів, постанов чи думкою авторитетних фахівців. Фотографії, уривки спогадів та архівні документи перетворюють «комікс» на розгорнутий лонгрид.

Нерозвиненість простору графічного репортажу пояснюється як відсутністю традиції сприйняття коміксного зображення, так і формуванням нових традицій української репортажної та ілюстраційної культури. Потужний розвиток художнього/літературного репортажу почасти підтверджує думку про словоцентричність українського культурного простору, тим більше, що ознаки вдалого художнього репортажу дотичні до коміксової журналістики і містять, за визначенням фундаторів та провідників головного репортажного медіа України reporters.media, наступні елементи: конфлікт, сильну історію та фактурних героїв, сюжет і драматургічну композицію, ефект присутності (описи, діалоги, деталі), просту людську мову, паралельну метафізичну історію. Навіть побіжне порівняння дозволяє говорити про загальні передоснови розвитку затребуваних гостросоціальних журналістських жанрів. Показово, що художній репортаж своїм завданням, як i коміксова журналістика, бачить вимогу фундатора «нового журналізму» Т. Вулфа «запалити читача і змусити його задуматися». Якісний контент проєктів онлайнжурналу The Ukrainians, потім Reporters, активне залучення молодих журналістських талантів через конкурси, зустрічі, семінари та навчальні програми дозволяє високо оцінити перспективи та можливості цього вагомого журналістського напрямку.

3 іншого боку, в Україні з'являються художні об'єднання, що пропонують альтернативний візуальний продукт, на кшталт проєкту Pictoric, що вибудовує свою стратегію ілюстрування як медіапосередника між містом і городянином, клієнтом і художньою концепцією, повсякденністю і незвичайним. «Людям потрібні проєкти, коли просто і зрозуміло без перекладача можна дізнатися щось нове або краще зрозуміти старе», - говорить співзасновник проєкту О. Грищенко (Ілюстрація як медіа. Telegraf.Design. 2018. 4 вересня). Саме з художниками Pictoric Б. Філоненко створив книгу «Тіні забутих предків. Графічні історії» (Київ : Артбук, 2016), яку у передмові назвав комік-буком. Унікальність і знаковість цього проєкту не тільки у незвичайному способі комеморації, що об'єднує інтерв'ю-спогади та ілюстрації (портрети, стрипи, розкадровки, шаржі) у єдності сторителінгу, але й у самовизначенні своєї роботи авторами як коміксжурналістики через роботу з пам'яттю. «Тобто фіксація не самої реальності, а реакції на неї. Ми долучаємо документальні речі, але посилання на них - мінімальні... Оскільки є дуже мало точного фактажу, ми будемо давати ці маленькі спогади і документи, з яких можна скласти якусь картинку. Тому більшою мірою це робота уяви читача, глядача», - характеризує свій проєкт Б. Філоненко в інтерв'ю Читомо («Тіні забутих предків. Графічні історії». Спроба порозумітися зі спогадами. Читомо. 2016. 21 березня). У намаганні продовжити традиції 
автори звертаються до минулого, але вже у сучасних сприйняттях, оцінках, а головне - мові: відрожена коміксним наративом пам'ять про культове кіно і людей, що його створювали, повертається 3 архівного історичного минулого, осучаснюється формою представленості матеріалу, а головне - актуалізованими і такими «живими» деталями повсякденності, характерними рисами учасників зйомок, різними кутами погляду на події: спомини головних героїв (оператора Ю.Іллєнка, актриси Л. Кадочникової, композитора М. Скорика, поета І. Драча) доповнюються інтерв'ю 3 невідомими широкому загалу співробітниками картини та пересічними жителями карпатських сел та верховин, де проводилися зйомки. Ця «різнофокусність» усвідомлений вибір авторів книги, анонсований у передмові до видання: «Це не збірка остаточних фактів чи об'єктивно поданих подій, які трапилися у 1960-х роках. Комікс $€$ формою, що дозволяє уникнути тональності "остаточної істини», даючи змогу закарбувати точку зору, погляд, згадку, затягуючи їх усі у поліфонічний вир».

Звертаємо увагу, що вищезазначений комікс був артоб'єктом на масштабній музейній експозиції у Мистецькому Арсеналі «Тіні забутих предків. Виставка» (23 березня - 10 квітня 2016 р.), де були представлені етнографічні матеріали, музика, відео, присвячені відомій стрічці С. Параджанова. Чуттєва синестезія мультимедійної композиції, анонсована кураторами виставки, вилилася потім і у цілісний проєкт комікс-буку.

3 виставки «На межі» (8 квітня 2011 р.) почалася історія соціального проєкту українки Ольги Трусовї та відомого комікс-журналіста Ден Арчера, де були представлені реальні історії українців-мігрантів, що стали жертвами торгівлі людьми. Проєкт реалізований за підтримки програми ім. Фулбрайта Міжнародного інституту освіти, Представництва Міжнародної організації з міграції в Україні, громадських організацій та Посольства США в Україні.

У передмові до інтернет-проєкту Д. Арчер зазначає: «Моя мета як журналіста, який працює в жанрі коміксу, полягає в тому, щоби подати історію у цікавій з візуальної точки зору формі та стисло передати великий обсяг інформації читачам, для яких ця тема $\epsilon$ новою. Від малюнка до малюнка читач відтворює ланцюжок подій і ставить себе на місце їх учасників, що допомагає побачити проблему в новому світлі, безпосередньо доторкнутися до неї. Я мав бути ретельним та уважним до деталей, щоб якомога точніше викласти кожну історію і переконливо показати людський вимір торгівлі людьми, який часто залишається непоміченим. Я сподіваюся посилити зв'язок між читачем та представленими тут історіями, включивши до збірки додаткову інформацію, а посилання та перелік джерел інформації наприкінці дадуть змогу читачеві самостійно поглибити свої знання щодо проблеми» [29].

Представлені 7 історій - це інтерв'ю 3 пацієнтами реабілітаційного центру Представництва Міжнародної організації з міграції (МОМ) в Україні. Кожна історія містить: передмову, що включає загальні факти торгівлі людьми і опис реальних юридичних справ потерпілих; 3- 6-сторінковий комікс у темних тонах, стилістично єдиний, 3 чіткими персоніфікованими героями, підкреслено схарактеризованими образами злодіїв та постраждалих; репліки у традиційних мовних бульбашках (speech balloon) доповнені врізками описового оповідального характеру. Єдності тексту додають інфографічні елементи (мапи, художні портрети героїв сюжетів та авторів проєкту, кольорові малюнки пацієнтів реабілітаційного центру), фактологічні врізки, корисні посилання, довідки для дзвінків на гарячу лінію. Жіттєописи жінок і чоловіків подані у хронологічній послідовності 3 перерваним невизначеним сюжетом (3 історії) або з сюжетним розвитком подій вже після повернення 3 неволі (4 оповіді). Показовою є остання оповідь «Зірка Сходу», де героїня, повернувшись на батьківщину з сексуального рабства, не знайшла себе і вирішила, що у турецькому борделі з сутенером їй було краще. Трагічний і почасти песимістичний у показі картин реального життя, комікс ставить на меті привернути увагу громадськості, викликати співчуття, по можливості, убезпечити молодих дівчат та юнаків від долі героїв книги. Усна історія, подана через опитування та інтерв'ю учасників, надає максимальної реалістичності (і трагічності!) проєкту.

Соціальний запит та підтримка міжнародних організацій сприяли появі ще одного цікавого видання «Перекресток: девять историй о войне и насилии» (2017). Як зазначають автори, в сучасних 3МІ мало місця для історій людей, а ще менше - для їх голосів. У продовження уже укоріненої стилістики усної історії, книга об'єднує біографічні інтерв'ю, що дозволяє зрозуміти не тільки події, а й їх значення для людини. «Замість відтворення дат, фактів і цифр, усна історія розповідає історії... життя " [30, с. 4]. На відміну від коміксу «На межі», форми достовірності та документальності значно розширені у графічному романі й представлені, перш за все, наскрізною героїнею - німецькою журналісткою, яка повернулася з Сирії і шукає історії людей, яких трагічно зачепила війна. Метафора потягу, на якому їде героїня (Київ-війна), унаочнюється життєвими історіями сусідів по вагону, їхніх близьких та знайомих: кримчанка, що, відірвавшись від рідної землі, болісно шукає себе в Україні, університетський викладач стає добровольцем, а потім волонтером, дівчина, яка не може знайти брата і стикається з бездушністю бюрократичної машини, звичайні пересічні родини, які втратили бізнес, дім, здоров'я, потворне і страхітливе життя на окупованих територіях, де «нова влада» відтворює заповідник жорстокості та цинічної зневаги до чужого життя. Безкомпромісні у винесенні приговору, автори коміксу намагаються у повсякденній реальності військового буття, чи то на фронті, чи в тилу, навіть на окупованих територіях побачити людські долі в контексті історико-політичних подій. При всій узагальненості реальний світ проривається різними формами аутентифікації: через деталізований простір міських локацій (вокзал у Львові, Донецьку, симферопольські будівлі); через наскрізну героїню (ії питання та заохочення до розповідей стають двигуном сюжетного розгортання); змінюється протягом розповіді й ступінь занурення у причини та пояснення 
людських вчинків - від зрозумілого і виправданого патріотизму («По зову сердца») до неоднозначного вибору залишитися у Донецьку і поваги до цього непростого рішення героїні новели «Кто-то должен остаться». Цей емоційний рівень створення мета-історії у книзі представляється найскладнішим: важко пережити страшні події, ще важче повернутися до них у спогадах і увести читача у свій особистісний простір. У цьому процесі «чуттєвої безпосередності» [20, р. 14] і вражаюча глибина емпатичного занурення, i проблема критичного сприйняття - адже максимально суб'єктивований простір оповіді залишає мало шансів для вдумливої критики. Доповнює цей процес фактологічна післямова, де метафора шляху наповнюється різноплановими значеннями - це і шлях країни, і окремих її громадян, дітей, жінок, переселенців, зниклих без вісті, загиблих. Це шляхи понівечених доріг з географічних мап і зламаних доль героїв графічного роману.

\section{3. Обговорення}

Трагічні сторінки української історії сьогодні активно переосмислюються та відтворюються різними видами мистецтв. Так, до теми Голодомору звертаються художники («Українські зошити» автор, італійськиї художник Ігор Трувері, назвав «репортажем за допомогою малюнків»), кінорежисери («Ціна правди» (2019) польської режисерки Агнешки Холланд про очевидця українського голоду британського журналіста Гаррета Джонса); серіал «Чорнобиль» від НВО у 2019 р. здобув премію «Золотий глобус» як найрейтинговіша міні-стрічка. Можна лише із сумом констатувати, що своя трагедія, ставши «чужою» історією чи творчою подією, повертається до нас 3 відчуттям відстороненого пережитого досвіду, який так болісно ми тільки-но намагаємся зробити емпатично-власним. Тому доволі складно, попри усталену традицію, віднести до коміксової журналістики твори біографічного жанру. Так, одним із творців «Перекрестка» був С. Захаров, відомий донецький художник, автор графічного роману "Діра» (Київ : Люта справа, 2016). Свою мальовану історію 3 полону у донецькій катівні С. Захаров назвав репортажем, визнаючи потужність та дієвість формату перед звичайним описом (У нас у Дірі. Книжка про життя під "ДНР». Радіо Свобода. 2019. 7 серпня). Залучити цей графічний роман до комікс-журналістики можна умовно, як і текст М. Сатрапі «Персеполіс», - автобіографія, попри самовизначення героїв, скоріше, жанр документалізованої графічної нарації. Стрижневим у становленні коміксової журналістики ми все ж визначаємо цілеспрямований пошук документальної інформації.

\section{4. ВИсновок}

Документалізований комікс представлено новітньою комікс-критикою у трьох головних наративних площинах: історія, документ, журналістика. Остання, як нам бачиться, вийшла далеко за межі візуалізованої журналістської оповіді, сьогодні термін «коміксова журналістика», як широке визначення, об'єднує доволі різні за форматом, тематикою й проблематикою явища: від стрипів і карикатур до розгорнутих репортажів та графічних романів. Комікс, з його особливим хронотопом та графічною стилістикою, принциповою відкритістю до синтетичних утворень та експериментів, виявився потужним засобом привернути увагу до травматичних подій не такого вже далекого минулого та увести читача у простір комеморації та співучасті.

\section{References}

1. Weber, W., \& Rall, H.-M. (2017) "Authenticity in comics journalism Visual strategies for reporting facts", Journal of Graphic Novels and Comics, 8(4), pp. 376-397. doi: 10.1080/21504857.2017.1299020.

2. Hudoshnyk, O. (2019) "Documentary comics in modern scientific discourse and Ukrainian comics space", Communications and Communicative Technologies, 19, pp. 3240. doi: 10.15421/291905.

3. McCloud, S. (2019) Understanding Comics: The Invisible Art. Kyiv: Native language [Ridna Mova].

4. Filonenko, B. (ed.) (2018) Comics in a Museum of Modern Art [Hans Ulrich Obrist, Robert Crumb, Art Spiegelman, John Carlin, Borys Filonenko]. Kharkiv: IST Publishing.

5. Sacco, J. (2012) Journalism. New York: Metropolitan Books.

6. Sacco, J. (2012) "The Myth of Objective Journalism". Available at: https://thequietus.com/articles/10916-joe-saccojournalism-interview (Accessed: 19 June 2019).

7. Archer, D. (2011) "An Introduction to Comics Journalism, in the Form of Comics Journalism". Available at: http://www.poynter.org/latest-news/top-stories/143253/anintroduction-to-comics-journalism-in-the-form-of-comicsjournalism/ (Accessed: 19 June 2019).

8. Polgreen, E. (2011) "What Is Graphic Journalism". Available at: http://www.hoodedutilitarian.com/2011/03/whatis-graphic-journalism/ (Accessed: 05 December 2019).

9. Polgreen, E. (2013) Interview: Symbolia Editor Erin Polgreen on Graphic Journalism. Available at: https://goodereader.com/blog/interviews/interview-symboliaeditor-erin-polgreen-on-graphic-journalism-for-the-tablet (Accessed: 05 December 2019).

10. Duncan, R. (ed.) (2018) Comics Studies Here and Now. New York: Routledge.

11. George-Palilonis, J. (2017) A practical guide to graphics reporting. New York: Routledge. doi: 10.4324/9781315709574.

12. Schlichting, L., (2016) "Interactive Graphic Journalism", VIEW Journal of European Television History and Culture, 5(10), pp. 22-39. doi: 10.18146/2213-0969.2016.jethc110.

13. Schack, T. (2013) "A failure of language: Achieving layers of meaning in graphic journalism", Journalism: Theory, Practice \& Criticism, 15(1), pp. 109-127. doi: 10.1177/1464884913486022.

14. Rall, H., Wang Ziyan, A. \& Weber, W. (2013) "Comics Journalism: Insights into a New Genre", in: CONFIA, International Conference on Illustration \& Animation, Porto, 29-30 November pp. 347-365. Instituto Politécnico do Cávado e do Ave. Available at: http://www.confia.ipca.pt/files/confia_2013_proceedings.pdf (Accessed: 17 December 2019).

15. Earle, H. (2019) "Comics and Graphic Novels", in O'Gorman, D., Eaglestone, R. (eds.) The Routledge Companion to Twenty-First Century Literary Fiction. New York: Routledge. 
16. Duncan, R., Taylor, M.R., \& Stoddard, D.J. (eds.) (2016) Creating Comics as Journalism, Memoir and Nonfiction. London, United Kingdom: Taylor \& Francis Ltd.

17. Mickwitz, N. (2016) "Nonfiction Comics and Documentary", in: N. Mickwitz, Documentary Comics: Graphic Truth-Telling in a Skeptical Age. New York: Palgrave Macmilla. doi: 10. 1057/9781137493323_2.

18. Wysocki, L. (2019) "Linking research and practice: qualitative social science data collection at a UK comics convention", Journal of Graphic Novels and Comics, 10 (5-6), pp. 505-524. doi: 10.1080/21504857.2018.1524393.

19. Carano, K. T., \& Clabough, J. (2016) “Images of Struggle: Teaching Human Rights with Graphic Novels", The Social Studies, 107(1), pp. 14-18. doi: 10.1080/00377996.2015.1094723.

19. Salmi, C. (2019) "Visualizing the World: Graphic Novels, Comics, and Human Rights", in: Parikh, C. (ed.) The Cambridge Companion to Human Rights and Literature. Cambridge: Cambridge University Press, pp. 178-193. doi: 10.1017/9781108698511.014.

20. Bake, J., \& Zöhrer, M. (2017) "Telling the stories of others: claims of authenticity in human rights reporting and comics journalism", Journal of Intervention and Statebuilding, 11(1), pp. 81-97. doi: 10.1080/17502977.2016.1272903.

21. Kavaloski, J. (2019) "Discordant discourses: history and journalism in the graphic novels of Joe Sacco", Journal of Graphic Novels and Comics, 10 (1), pp. 122-139. doi: 10.1080/21504857.2018.1431801.

22. Ecke J., \& McFarland, G.H. (eds.) (2010) Comics as a Nexus of Cultures: Essays on the Interplay of Media, Disciplines and International Perspectives. North Carolina, London: McFarland.

\section{Hudoshnyk O. Transmedial narratives of comic journalism: world and ukrainian experience}

Continuing the research of the world and Ukrainian documentary comics, this article presents comics journalism in the context of theoretical approaches, genre and thematic definitions and characteristics. Comics journalism is considered as an umbrella term, allowing to combine interactive comics-reporting, caricature, patch and graphic novel into a single space of graphic storytelling. The transmediality of the comics, generated by the visualcentricity of the modern world and the tendency to mix different forms and styles, provides journalistic materials with empathetic emotionality, intertextuality and polymodality. However, traditional journalistic standards are not refuted, their meaning are motivated by new information challenges and technological capabilities of contemporary graphic art. Compliance with the requirements of objectivity and credibility of comics journalists was the decisive and most debatable issue. Based on visual authentication strategies (according to W. Weber and H.-M. Rall), the research features the Ukrainian-themed materials on global comics platforms, newspapers and national content of Ukrainian comic journalism. The latter is represented by the certain projects of newspapers, news sites, blogs, cycles of graphic stories on social issues, graphic novels and comic books. Despite the involvement of the Ukrainian information space in the alternative forms of presenting relevant social and political material, the national media, mass authors and public initiatives do not appeal to comic journalism in practice.

Keywords: documentary comics; comics journalism; transmediality; graphic storytelling; authentication strategies. 